\title{
車輪走行実験による沈下過渡状態におけるせん断変形モデル有効性の評価
}

\author{
水上 憲明 ${ }^{* 1}$, 石上 玄也 ${ }^{* 2}$, 吉光 徹雄 ${ }^{* 3}$, 久保田 孝 $^{* 4}$
}

\section{Evaluation of the shear deformation model in the process of wheel sinking by the wheel experiment}

\author{
Noriaki MIZUKAMI $^{* 1}$, Genya ISHIGAMI ${ }^{* 2}$, Tetsuo YOSHIMITSU*3 and Takashi KUBOTA*4 \\ ${ }^{* 1}$ Chuo University \\ 1-13-27, Kasuga, Bunkyo-ku, Tokyo 112-8511, Japan \\ ${ }^{* 2}$ Keio University \\ 3-14-1 Hiyoshi, Minatokita-ku, Yokohama, Kanagawa 223-8522, Japan \\ ${ }^{*},{ }^{*}$ ISAS/JAXA \\ 3-1-1 Yoshinodai, Chuo-ku, Sagamihara, Kanagawa 252-5210, Japan
}

\section{Received 7 October 2014}

\begin{abstract}
Soft soils cover on planetary surfaces, so the wheels for exploration rovers easily slip. Understanding an interaction between a wheel and soft soils is important for a traction control to improve rover traversability. The interaction between the wheel and soft soils has been studied in a field of terramechanics. Since the classical terramechanics-based wheel model considers only a static state of a wheel sinkage, the wheel model is not applicable to the wheel sinkage and slip. Thus the dynamic normal stress model and shear deformation model were proposed to deal with the problems of the wheel sinkage and the slip. The dynamic normal stress model was proposed by considering the wheel sinking velocity and a variation of soil state for solving the problem of wheel sinkage. And the shear deformation model was proposed by considering the shear characteristics for solving the problem of wheel slip. The shear deformation model was formulated by the shear test. The simulation verified the validity of the dynamic normal stress model and the shear deformation model in the transient state. In this paper, a single wheel experiments was performed to evaluate the shear deformation model by comparing the simulation results and the experimental results. Then the characteristics of the wheel sinkage and slip and the effectiveness of the model were confirmed.
\end{abstract}

Key words : Wheel dynamic sinkage, Shear deformation modulus, Wheel acceleration, Wheel experiment

\section{1. 緒言}

多くの探査ローバによって月・惑星の表面探査が行なわれている。これまでのローバミッションでは移動機構 として車輪機構が採用されているが，軟弱地盤においてスリップしやすいという問題がある．けん引力が十分大 きくならない場合，車輪移動速度が増加しないのでスリップは増大する．それとともに車輪沈下量が増加する. その結果ローバは前進できなくなり車輪スタックしてしまう。この問題の回避のためにテラメカニクス (Bekker,

No. 14-00514 [DOI: 10.1299/transjsme.14-00514], J-STAGE Advance Publication date : 31 March, 2015

*1 正員, 中央大学理工学部電気電子情報通信工学科（广112-8551 東京都文京区春日 1-13-27）

*2 正員, 慶應義塾大学理工学部機械工学科（干223-8522＼cjkstart神奈川県横浜市港北区日吉 3-14-1）

*3 宇宙航空研究開発機構（干252-5210 神奈川県相模原市中央区由野台 3-1-1）

*4 正員, 宇宙航空研究開発機構

E-mail of corresponding author: mizukami@elect.chuo-u.ac.jp 


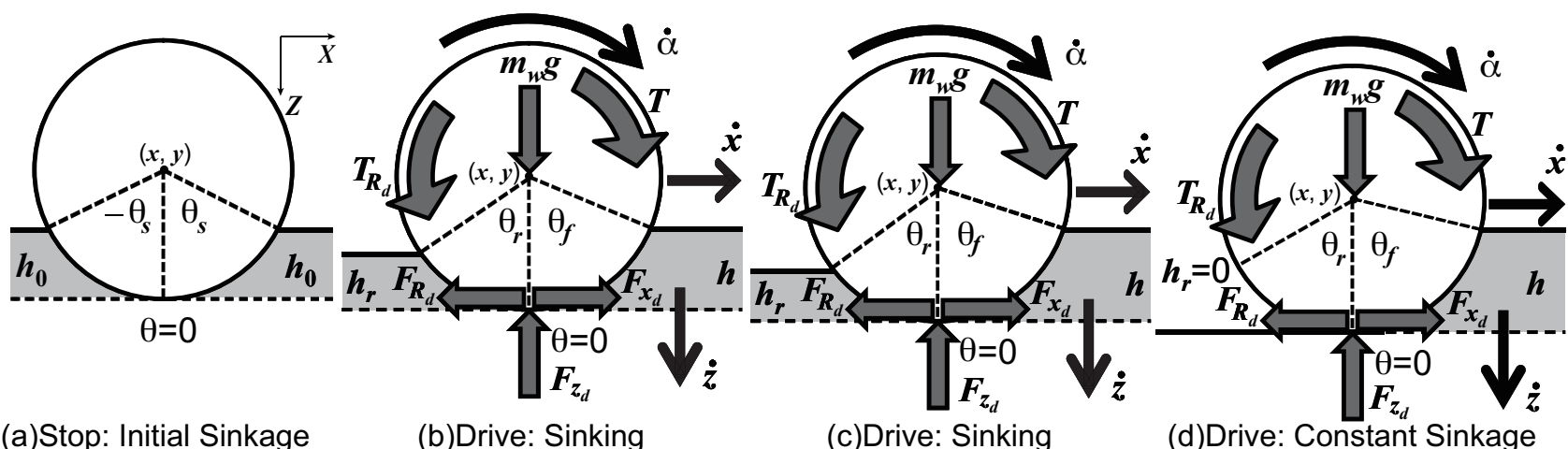

(a)Stop: Initial Sinkage

(b)Drive: Sinking

(c)Drive: Sinking

(d)Drive: Constant Sinkage

Fig. 1 Driving wheel on soft soil

1956)(Wong, 1978) と呼ばれる車輪と砂の相互作用に着目した力学的解析が考慮され，スリップを低減するための 研究が様々なアプローチで行われている (Brooks, et al., 2005)(Gu, et al., 2007)(Iagnemma and Dubowsky, 2000)(飯塚 他, 2007: Iizuka, et al., 2008)(Ishigami, et al., 2007: 石上他, 2011)(成田他, 2011)(大槻他 2010)(Reina, et al., 2006)(須 藤他, 2011)(Yoshida and Hamano, 2002).

本研究では車輪の駆動制御によってスリップの低減を実現する方法に着目する. 車輪が駆動を開始するとき通 常, 車輪は加速し等速で走行し減速して停止する. 従来のテラメカニクスは等速走行している沈下定常状態での 走行メカニズムをモデル化しているのみである. 初期沈下している車輪が加速によってどの様な状態変化を経て, 沈下定常状態で等速走行するのかについての走行メカニズムは明らかになっていない. 軟弱地盤において安全か つ効率的に走行するためには車輪スリップを小さく抑え, 車輪スタックを回避することであるので動きだし加速に よる沈下・スリップ増大を防止することは重要であると考える. 本研究の目的は車輪の駆動制御によってスリッ プ低減を行なうための動的沈下を考慮に入れた車輪モデルの構築である.これまでに動的垂直応力モデルとせん 断変形モデルを提案しシミュレーションにより妥当性を確認した (水上 他, 2013). 本論文は一面せん断試験の結果 を基に提案したせん断変形モデルを車輪に応用した場合の有効性の評価を単車輪実験によって行なう。せん断変 形モデルのパラメータは実験により決定し, 実験結果とシミュレーション結果を比較することで過渡状態におけ るせん断変形モデルの有効性を評価する.

本論文の構成は次の通りである. 第 2 章では車輪の沈下運動を考慮に入れた車輪ダイナミクスモデルと動的沈 下を考慮した動的車輪モデルを示す. 第 3 章では単車輪実験を行ない車輪の沈下・スリップ特性を検証し, シミュ レーション結果と実験結果を比較することで提案モデルの有効性を評価する.

\section{2. ダイナミクスモデル}

軟弱地盤を走行する岡性車輪の沈下開始から沈下定常状態に達するまでの過程に焦点を当て図 1 に示すように 車輪の座標系を定義する。この座標系において車輪進行方向の変位を $X$, 車輪沈下方向の変位を $Z$ とす. 車輪が 停止して初期沈下状態にある車輪中心の座標を原点とし $(x, z)=(0,0)$ とする. $x$ は車輪移動距離, $z$ は車輪沈下変位 を示す.

\section{$2 \cdot 1$ 車輪ダイナミクスモデル}

本節では車輪の沈下運動を考慮に入れた車輪ダイナミクスモデルについて述べる. 車輪の進行方向, 回転方向, 沈下方向の運動方程式を以下に示す。

$$
\left\{\begin{array}{l}
m_{w} \ddot{x}=F_{x_{d}}-F_{R_{d}} \\
I_{w} \ddot{\alpha}=T-T_{R_{d}} \\
m_{w} \ddot{z}=m_{w} g-F_{z_{d}}
\end{array}\right.
$$

$\ddot{x}$ は車輪移動加速度, $\ddot{\alpha}$ は車輪回転角加速度, $\ddot{z}$ は車輪沈下加速度, $m_{w}$ は車輪質量, $I_{w}$ は車輪慣性モーメント, $T$ は車輪トルク, $g$ は重力加速度である. $F_{x_{d}}$ は動的駆動力, $F_{R_{d}}$ は動的走行抵抗力, $F_{z_{d}}$ は動的重直抗力, $T_{R_{d}}$ は動 
的外乱トルクである. 状態方程式は以下の式 (2) になる.

$$
\dot{q}=f(q)+B u
$$

ここで,

$$
\begin{aligned}
& q=\left[\begin{array}{llllll}
\dot{x} & x & \dot{\alpha} & \alpha & \dot{z} & z
\end{array}\right]^{T}, \quad u=T \\
& f(q)=\left[\begin{array}{c}
\frac{1}{m_{w}}\left(F_{x_{d}}-F_{R_{d}}\right) \\
\dot{x} \\
-\frac{1}{I_{w}} T_{R_{d}} \\
\dot{\alpha} \\
\frac{1}{m_{w}}\left(m_{w} g-F_{z_{d}}\right) \\
\dot{z}
\end{array}\right], \quad B=\left[\begin{array}{c}
0 \\
0 \\
\frac{1}{I_{w}} \\
0 \\
0 \\
0
\end{array}\right]
\end{aligned}
$$

$\dot{x}$ は車輪移動速度, $\dot{\alpha}$ は車輪回転角速度, $\dot{z}$ は車輪沈下速度, $\alpha$ は車輪回転角度である.

\section{2 動的沈下を考慮した車輪モデル}

\subsection{1 動的車輪モデル}

動的沈下を考慮した動的垂直応力モデル $\sigma_{d}(\theta)$ と動的せん断応力モデル $\tau_{d}(\theta)$ を用いて動的車輪モデルを以下 のように定義する. 動的駆動力 $F_{x_{d}}$ と動的走行抵抗力 $F_{R_{d}}$ を以下に示す.

$$
\begin{aligned}
& F_{x_{d}}=r b \int_{\theta_{r}}^{\theta_{f}} \tau_{d}(\theta) \cos \theta d \theta \\
& F_{R_{d}}=r b \int_{\theta_{r}}^{\theta_{f}} \sigma_{d}(\theta) \sin \theta d \theta
\end{aligned}
$$

$r$ は車輪半径, $b$ は車輪幅である. 動的けん引力 $F_{D P_{d}}$ を動的駆動力モデル $F_{x_{d}}$ と動的走行抵抗力モデル $F_{R_{d}}$ の差か ら以下のように定義する.

$$
F_{D P_{d}}=F_{x_{d}}-F_{R_{d}}=r b \int_{\theta_{r}}^{\theta_{f}}\left[\tau_{d}(\theta) \cos \theta-\sigma_{d}(\theta) \sin \theta\right] d \theta
$$

動的垂直抗力モデル $F_{z_{d}}$ を以下に示す.

$$
F_{z_{d}}=r b \int_{\theta_{r}}^{\theta_{f}}\left[\sigma_{d}(\theta) \cos \theta+\tau_{d}(\theta) \sin \theta\right] d \theta
$$

動的外乱トルクモデル $T_{R_{d}}$ を以下に示す.

$$
T_{R_{d}}=r^{2} b \int_{\theta_{r}}^{\theta_{f}} \tau_{d}(\theta) d \theta
$$

車輪入射角 $\theta_{f}$ は式 $(8)$ のように示す． $\theta_{f}$ は車輪前方が土袞と接触を開始する角度で車輪の鉛直下向きを $\theta=0$ とし て反時計回りに正の值となる.

$$
\theta_{f}=\cos ^{-1}\left(1-\frac{h}{r}\right)
$$

車輪沈下量 $h$ は式 (9) のように表す.

$$
h=h_{0}+z
$$

$h_{0}$ は車輪初期沈下量, $z$ は車輪沈下変位である. 車輪脱出角 $\theta_{r}$ は車輪後方が土㙵と接触する角度であり車輪走行 中に変化すると考える. 初期沈下時は車輪前方と後方に砂が接している状態で, 車輪の移動によって後方の砂の 接地面は減少していく. 接地面の減少は後方沈下量の減少によって起こると考える. 本論文では移動距離 $x$ の関 数として以下のように車輪脱出角 $\theta_{r}$ を示す. 車輪脱出角は移動量の増加にしたがい減少して定常状態での走行時 には $\theta_{r}(x)=0$ になる. $H$ は車輪脱出角の変化量を決めるフィッティングパラメータで, $\kappa$ は後方沈下量係数で 0.0 $\leq \kappa \leq 1.0$ の值となり初期沈下時の車輪脱出角 $\theta_{s}$ に対する比で後方沈下量を示す.

$$
\theta_{r}(x)=\kappa \theta_{s} e^{-H x}
$$

\subsection{2 動的車輪応力モデル}

テラメカニクスにおいて車輪に作用する力とトルクを構成する垂直応力とせん断応力について示す. 本論文で は動的沈下を扱う場合, 従来の垂直応力モデル (Bekker, 1956)(Wong and Reece, 1967) に対して沈下速度を考慮に 
入れせん断による土袞状態変化を車輪回転速度と移動速度の差である土袞のせん断速度 $[r \dot{\alpha}-\dot{x} \cos \theta]$ にって変 化するとして動的垂直応力モデル $\sigma_{d}(\theta)$ を以下のように提案した (水上他, 2013).

$$
\begin{aligned}
& \sigma_{d}(\theta)=\left\{\begin{array}{lc}
\left(\frac{k_{c}}{b}+k_{\phi}\right)\left\{r\left[\cos \theta-\cos \theta_{f}\right]\right\}^{n}+\beta_{f}(\theta) \dot{z} \\
\left(\frac{k_{c}}{b}+k_{\phi}\right)\left\{r\left[\cos \left(\theta_{f}-\frac{\theta-\theta_{r}}{\theta_{m}-\theta_{r}}\left(\theta_{f}-\theta_{m}\right)\right)-\cos \theta_{f}\right]\right\}^{n}+\beta_{r}(\theta) \dot{z} & \left(\theta_{m} \leq \theta<\theta_{f}\right) \\
\beta_{f}(\theta)=\frac{\left\{\eta\left[\cos \theta-\cos \theta_{f}\right]\right\}}{(r \dot{\alpha}-\dot{x} \cos \theta)} & \beta_{r}(\theta)=\frac{\left\{\eta\left[\cos \left(\theta_{f}-\frac{\theta-\theta_{r}}{\theta_{m}-\theta_{r}}\left(\theta_{f}-\theta_{m}\right)\right)-\cos \theta_{f}\right]\right\}}{(r \dot{\alpha}-\dot{x} \cos \theta)}
\end{array}\right.
\end{aligned}
$$

$k_{c}$ は土壌の粘着応力係数, $k_{\phi}$ は土袞の内部摩擦係数, $n$ は土袞の沈下係数, $\eta$ はフィッティングパラメータであ る. $\theta_{m}$ は最大応力発生角で以下の式で表す.

$$
\theta_{m}=\left(a_{0}+a_{1} s\right) \theta_{f}
$$

$a_{0}, a_{1}$ は最大応力発生角定数で $a_{0} \approx 0.4,0.0 \leq a_{1} \leq 0.3$ の值が用いられる (Wong and Reece, 1967).

せん断応力 $\tau(\theta)$ は, はじめせん断変位の増加に従い急増加し, その後せん断変位の増加とともに一定の值に近 づいていく.Janosi らによってこの様なせん断変位 $j$ に対するせん断応力 $\tau(\theta)$ はモデル化されている (Janosi and Hanamoto, 1961). 本論文では動的せん断応力モデル $\tau_{d}(\theta)$ を動的垂直応力モデルを用いて以下のように示す.

$$
\tau_{d}(\theta)=\left(c+\sigma_{d}(\theta) \tan \phi\right)\left[1-e^{-j(\theta) / k}\right]
$$

$c$ は土袞の粘着圧力, $\phi$ は土壌の内部摩擦角, $k$ はせん断変形係数である. せん断変位 $j(\theta)$ は以下の式で表す.

$$
j(\theta)=r\left[\theta_{f}-\theta-(1-s)\left(\sin \theta_{f}-\sin \theta\right)\right]
$$

ここでスリップ率 $s$ は車輪回転速度 $r \dot{\alpha}$ と車輪移動速度 $\dot{x}$ から以下の式で表す．スリップ率は- $1.0 \leq s \leq 1.0$ の範囲 になる。

$$
s= \begin{cases}\frac{r \dot{\alpha}-\dot{x}}{r \dot{\alpha}} & (r \dot{\alpha}>\dot{x}: \text { driving }) \\ \frac{r \dot{\alpha}-\dot{x}}{\dot{x}} & (r \dot{\alpha}<\dot{x}: \text { braking })\end{cases}
$$

沈下過渡状態における車輪に作用する力は, これら動的垂直応力モデルと動的せん断応力モデルから構成され る. 特に動的駆動力モデルを構成する動的せん断応力モデル $\tau_{d}(\theta)$ のパラメータであるせん断変形係数 $k$ に焦点を 当て, これまでに (水上他, 2013) では, 沈下過渡状態におけるせん断変形モデルを提案した. 過渡状態での車輪の 状態変化において, せん断特性が変化すれば, せん断変形係数は定常状態で異なった值になると考える. そこで せん断変形係数を変数として扱えるかどうかせん断試験によって検証した．せん断試験の結果としてせん断変形 係数とせん断加速度の関係を図 2 に示す. せん断加速度が大きくなるほどせん断変形係数は大きくなる傾向にあ り変数として扱えることが示された。

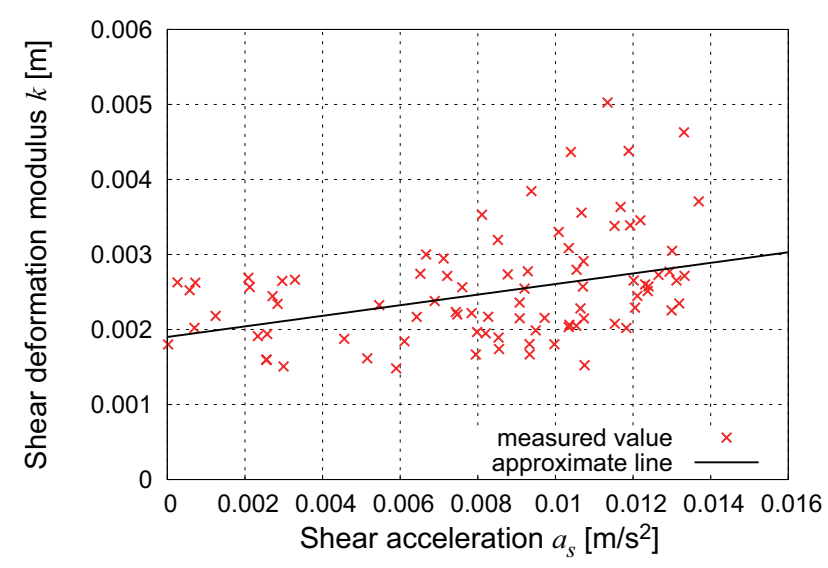

Fig. 2 Relationship between the shear deformation modulus and shear acceleration

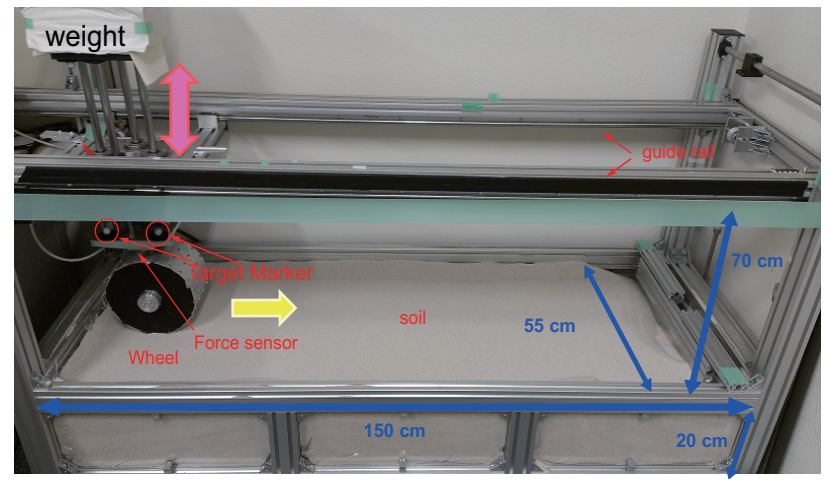

Fig. 3 A picture of the single wheel experimental device 
沈下過渡状態におけるせん断変形係数 $k$ はせん断加速度とせん断変形係数の関係から車輪に応用した場合, 車 輪加速度 $r \ddot{\alpha}$ によって変化する関数 $k(r \ddot{\alpha})$ として, 以下のように提案した (水上他, 2013).

$$
k(r \ddot{\alpha})=A \cdot r \ddot{\alpha}+k_{0}
$$

$\ddot{\alpha}$ は車輪回転角加速度, $A$ と $k_{0}$ はフィッティングパラメータである.

\section{3. 単車輪走行実験}

本章では車輪回転加速による沈下・スリップ特性を把握するため，またシミュレーション結果と比較すること でせん断変形モデルの有効性の評価を行なうために単車輪走行実験を行なった.

\section{$3 \cdot 1$ 車輪走行実験システム}

本実験システムの構成図を図 3 に示す。本実験装置は実験装置上部のガイドレール部とガイドレールに沿って 水平移動する移動装置から構成される。移動装置には車輪部が連結されていて車輪の上部に設置された 6 軸力覚 センサで車輪が発生する力を計測する。また車輪用モータに取り付けられているエンコーダによって，車輪回転 角度を計測し車輪角加速度・速度を求める. その他車輪の移動変位, 沈下変位を計測するためにモーションキャ プチャー装置を使用する.

\section{$3 \cdot 2$ 車輪走行実験の結果}

車輪回転加速による沈下・スリップ特性を把握するために車輪回転速度の目標值を $r \dot{\alpha}=0.10 \mathrm{~m} / \mathrm{s}$ とし, 加速時間 $t_{a}=0.25,1.00,2.50,5.00$ 秒 (加速度 $r \ddot{\alpha}=0.40,0.10,0.04,0.02 \mathrm{~m} / \mathrm{s}^{2}$ ) とする走行実験を行なった. また $8 \mathrm{~kg}$ の錘 を移動装置上部に乗せ，車輪総荷重を常に一定である $13.65 \mathrm{~kg}$ とした。

図 4 はそれぞれの加速時間 $t_{a}$ に対して動的沈下が終了した時間 (沈下時間) $t$ と動的沈下量 $h_{d}$ の平均值を点で標 準偏差をエラーバーで表している. 図 5 は動的沈下が終了した時間 $t$ とスリップ率 $s$ の平均值を点で標準偏差をエ ラーバーで表している. 凡例はそれぞれの加速時間 $t_{a}$ を示している. 平均值と標準偏差は 14 のデータサンプルか ら求めている. 図 6 に表す模式図のように沈下量の増加は車輪加速後に一旦は落ち着くがその後, 再び徐々に増 加する傾向がみられた. その原因は $\dot{z}>0[\mathrm{~m} / \mathrm{s}]$ で振動的な変化を続けるためである. 本論文では加速による動的沈 下とスリップ率の変化量を把握するために, 沈下速度が増加後に減少に転じてから約 $\dot{z}<0.001[\mathrm{~m} / \mathrm{s}]$ になり沈下増 加が一旦落ち着く時刻までを沈下時間として, この時刻での沈下量とスリップ率を加速度による変化量として扱 うことにした。

有意水準 $5 \%$ で $t$ 検定を行なった結果，動的沈下量の平均值は加速時間 $t_{a}=0.25$ と $t_{a}=1.00$, 加速時間 $t_{a}=0.25$ と $t_{a}=5.00$ の関係において有意な差があることを確認した。 またスリップ率の平均值は加速時間 $t_{a}=0.25$ と $t_{a}=5.00$, 加速時間 $t_{a}=1.00$ と $t_{a}=5.00$ と加速時間 $t_{a}=2.50$ と $t_{a}=5.00$ の関係において有意な差があることを確認した. よって 実験結果から加速時間が小さい (加速度が大きい) ほど沈下時間は小さくなり, 動的沈下量とスリップ率は大きく なる傾向にあると考える．沈下過渡状態において車輪加速度が大きいほどせん断応力が小さくなり車輪に発生す

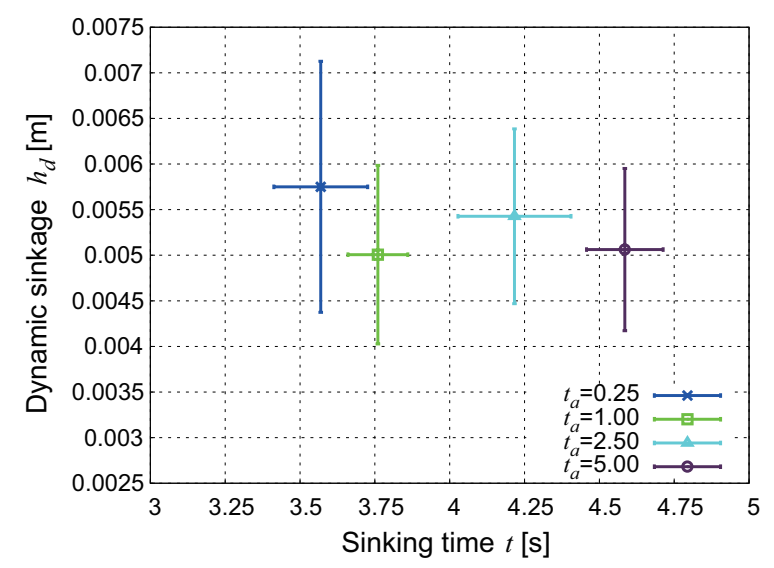

Fig. 4 Relationship between the dynamic sinkage and sinking time

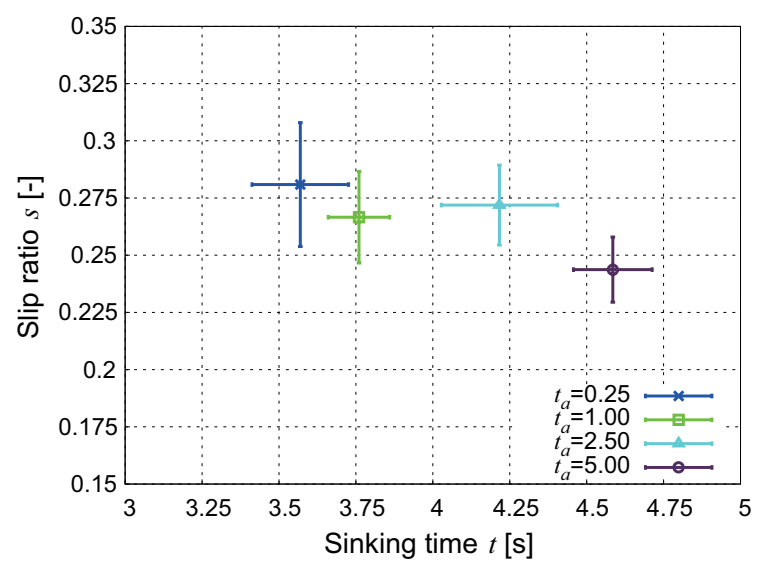

Fig. 5 Relationship between the slip ratio and sinking time 


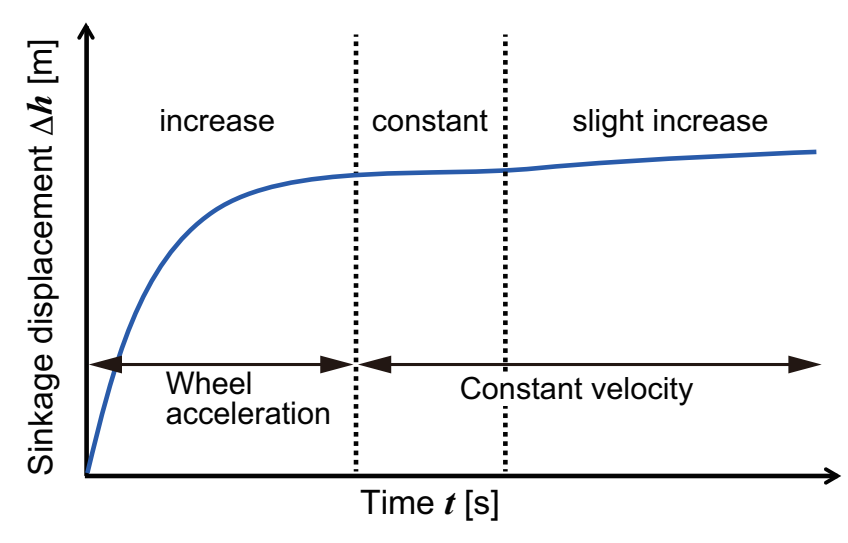

Fig. 6 Diagram of wheel sinkage

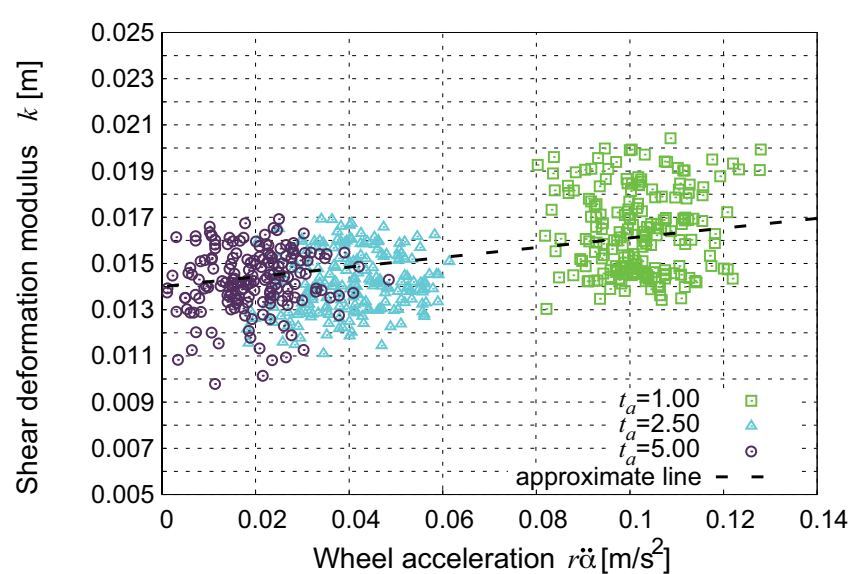

Fig. 7 Relationship between the shear deformation modulus and wheel acceleration

るけん引力が小さくなったためと考える. 故に車輪は十分な加速度が得られず移動速度が大きくならないために スリップ率が大きくなり，沈下量も大きくなった，走行実験結果は提案モデルを用いたシミュレーション結果と 同じ傾向となり, 車輪のスリップ低減のためには動き出しの加速の仕方が重要であることが分かった.

\section{$3 \cdot 3$ 走行実験によるせん断変形モデル有効性の評価}

走行実験結果とシミュレーション結果を比較しせん断変形モデルの有効性を評価する. 土䁃パラメータ $c$ と $\phi$ はせん断試験により推定, $k_{c}$ と $k_{\phi}, n$ はパラメータ調整して設定している(表 1$)$. 車輪パラメータは表 2 を使用 する. 図 7 は, 実験の計測值から推定したせん断変形係数 $k$ と車輪加速度 $r \ddot{\alpha}$ の関係である. 図中の破線はせん断 変形係数と加速度の近似直線で, その傾きと縦軸切片から式 (16) のせん断変形モデルのパラメータを $A=0.0211$, $k_{0}=0.014$ と決定した. また動的垂直応力モデルのパラメータは $\eta=150000$ とした. 式 (10)の車輪脱出角 $\theta_{r}(x)$ の パラメータは $\kappa=0.7, H=6.0$ とした.

図 8，9に実験結果とシミュレーション結果を同時にプロットした結果を示す.シミュレーションは時刻 $t=0.05$ 秒から開始している.この時刻の車輪回速度 $r \dot{\alpha}$ は加速時間から計算で求め, 車輪移動速度 $\dot{x}$ とスリップ率 $s$ は 0 以上の任意の值を与えた. 太線は式 (16) の提案モデルを用いて, 細線は従来モデルで緩い砂のせん断変形係数 $k=0.025$ の一定值としたシミュレーション結果である. 点とエラーバーは各時刻における計測值の平均值と標準偏 差を表している. 平均值と標準偏差は 14 のデータサンプルから求めている. 図 8 は時間に対する沈下変位である. 提案モデルと従来モデルを用いた場合のシミュレーション結果はともに加速時間が大きいほど沈下時間が大きく なる，その傾向は実験結果も同じである．沈下変位は動き出しの短時間のみシミュレーション結果と実験結果が ほぼ一致する．その後シミュレーションの沈下変位は増加していき実験結果より大きくなる. シミュレーション と実験の沈下変位の誤差は加速時間によって異なるが最大 $0.001 \mathrm{~m}$ である. 従来モデルを用いた場合の沈下变位 の誤差は約 $0.0015 \mathrm{~m}$ で提案モデルを用いた場合より大きくなる. 図 9 は時間に対するスリップ率の関係である. スリップ率は加速時間 $t_{a}=0.25$ 秒の場合, 動き出しからシミュレーション結果と実験結果は一致せず, シミュレー ションのスリップ率の方が大きくなる，その誤差は最大で 0.3 である. 加速時間 $t_{a}=1.00$ 秒の場合, 時刻 $t=2.5$ 秒 までシミュレーション結果と実験結果はほぼ一致する，その後シミュレーションのスリップ率は増加していき実 験結果より大きな值になる. その誤差は最大 0.1 である. 加速時間 $t_{a}=2.50$ 秒と 5.00 秒の場合, シミュレーション

Table 1 Soil parameters

\begin{tabular}{clcl}
\hline \hline Soil parameters & Unit & Values & Description \\
\hline$c$ & $\mathrm{~N} / \mathrm{m}^{2}$ & 761.84 & cohesion stress \\
$\phi$ & $\mathrm{deg}$ & 22.3 & internal friction angle \\
$k_{c}$ & $\mathrm{~N} / \mathrm{m}^{n+1}$ & 1000 & cohesion stress modulus \\
$k_{\phi}$ & $\mathrm{N} / \mathrm{m}^{n+2}$ & 5000000 & internal friction angle modulus \\
$n$ & & 1.1 & sinkage ratio \\
$a_{0}$ & & 0.40 & maximum stress angle modulus \\
$a_{1}$ & & 0.15 & maximum stress angle modulus \\
\hline
\end{tabular}

Table 2 Wheel parameters

\begin{tabular}{clcl}
\hline \hline Wheel parameters & Unit & Values & Description \\
\hline$m_{w}$ & $\mathrm{~kg}$ & 13.65 & wheel mass \\
$r$ & $\mathrm{~m}$ & 0.11 & wheel radius \\
$b$ & $\mathrm{~m}$ & 0.12 & wheel width \\
$I_{w}$ & $\mathrm{kgm}^{2}$ & 0.03025 & wheel inertia \\
\hline
\end{tabular}



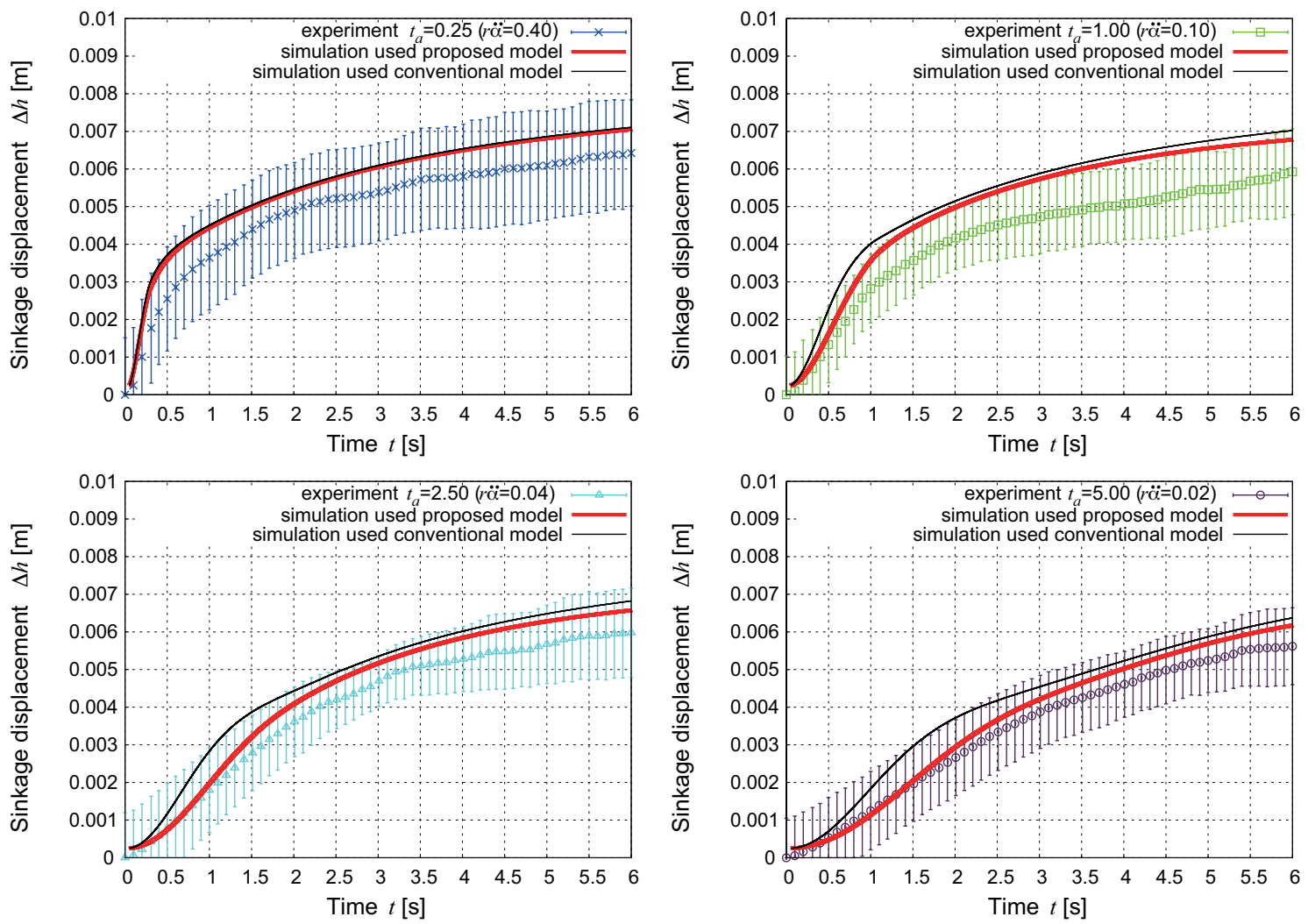

Fig. 8 Relationship between the sinkage displacement and time (experiment and simulation results)
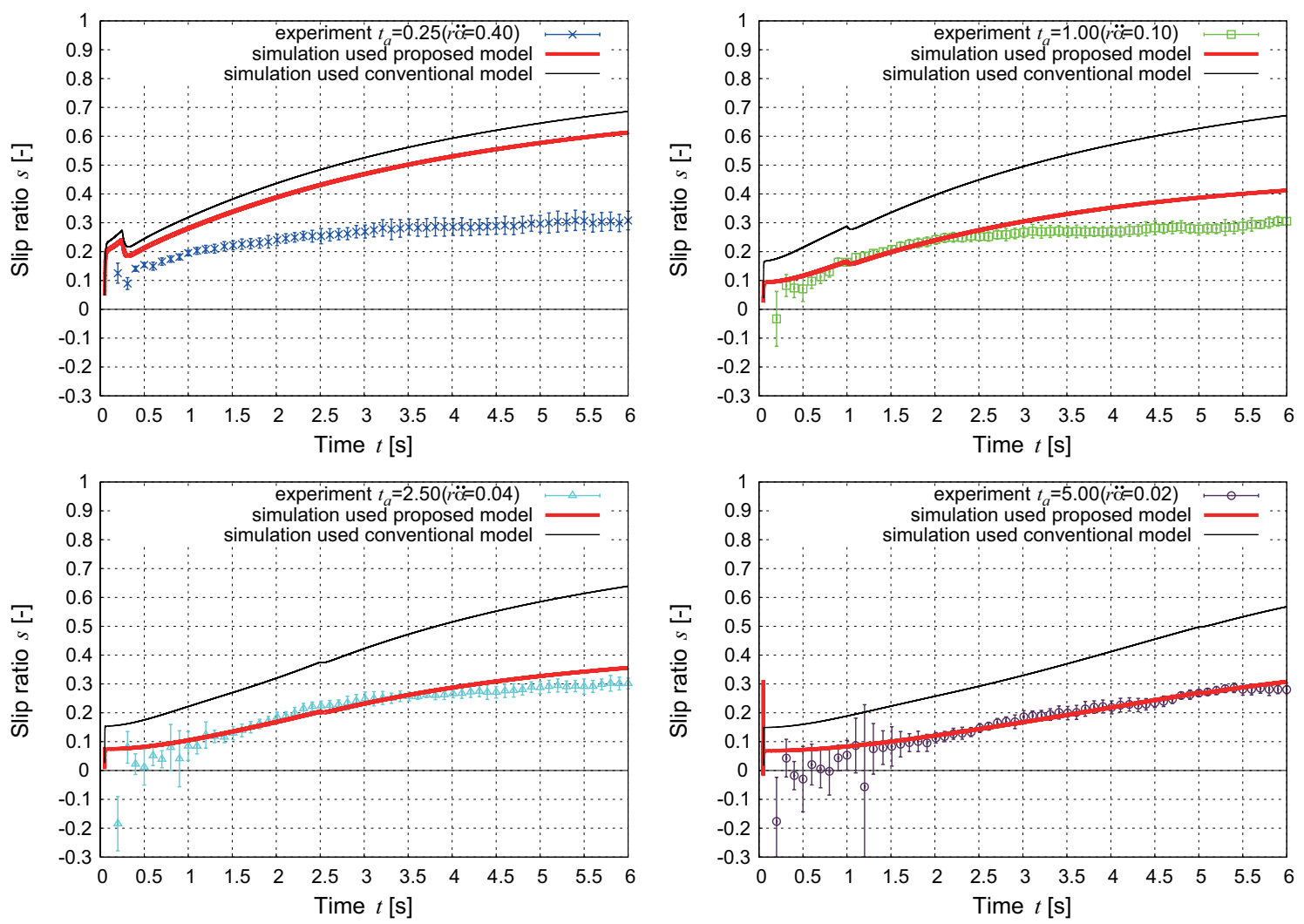

Fig. 9 Relationship between the slip ratio and time (experiment and simulation results) 
結果と実駼結果はほぼ一致する，従来モデルを用いた場合のスリップ率の誤差は約 0.35 で提案モデルを用いた場 合より大きくなる．提案モデルを用いた場合の沈下変位とスリップ率は，加速度が大きいほど大きくなる．それに 対して従来モデルを用いた場合, 加速度に関わらず同じ沈下変位, スリップ率になり走行実験で得た沈下特性と スリップ特性は表せない，実験結果とシミュレーション結果は完全には一致しなかった。その原因はシミュレー ションで使用した土壌パラメータが実験で使用した砂と異なる点と過渡状態において砂の状態を変化させる要因 が車輪加速度の他にもあるためであると考える．本論文ではその一つである車輪加速度を用いたモデル化を行な い, 実験とシミュレーションの比較から動き出しから定常状態までの定性的な一致を確認した。また従来モデル では表現できない加速度によるスリップ率の変化を表現できるので提案モデルを用いることで車輪の駆動制御に よって走行性能を向上させることが可能になると考える. 土壌パラメータの同定と実験とシミュレーションの比 較による沈下量・スリップ率の定量的な評価は今後の課題と考えている.

\section{4. 結論}

本論文では軟弱地盤を走行する単車輪の沈下・スリップの特性を把握するために単車輪走行実験を行なった．沈 下特性として車輪回転加速度が大きいほど動的沈下量が大きくなることが分かった．スリップ特性として動き出 しから徐々に増加していき加速度が大きいほどスリップ率が大きくなることが分かった。この沈下・スリップ特 性から車輪のスリップ低減のためには動き出しの加速の仕方が重要であることを示した．また走行実験から得ら れた計測值を用いてせん断変形モデルのパラメータの決定を行ない, 提案モデル有効性の評価を沈下過渡状態で の沈下・スリップ特性におけるシミュレーション結果と走行実験結果を比較することで行なった. 実験結果とシ ミュレーション結果は完全には一致しなかったが, 過渡状態においてせん断特性を変化させる要因として加速度 を用いたモデル化を行ない, 実験とシミュレーションの比較から定常状態までの定性的な一致を確認した.また 提案モデルは従来モデルでは表現できない加速度によるスリップ率の変化を表現できるので走行性能向上のため の車輪の駆動制御に利用できると考える.

今後の課題としては, 土袞パラメータの同定を行ない提案モデルの定量的な評価をする．そして，スリップ低減 を目的とした制御手法を構築し単車輪実験装置を用いてスリップの低減が行なえるかどうか検証する. 複数車輪 の走行時には, 他の車輪による走行面変化やスリップを考慮に入れる必要があので, 提案モデルを応用した複数 車輪走行についての検討も行なう. 軟弱地盤を走行するローバの複数車輪の相互作用を考慮にいれたトラクショ ンコントロールを実現するために，提案モデルのトラクションコントロールに対する応用を検討する.

文献

Bekker, M. G., Theory of land locomotion (1956), The University of Michigan Press.

Brooks, C., Iagnemma, K. and Dubowsky, S., Vibration-based terrain analysis for mobile robots, Proceeding of the 2005 IEEE International Conference on Robotics and Automation (2005), pp. 3415-3420.

$\mathrm{Gu}, \mathrm{K}$., Wei, Y. and Zhao, H. W. M., Dynamic modeling and sliding mode driving control for lunar rover slip, Proceedings of the 2007 IEEE International Conference on Integration Technology (2007), pp. 36-41.

Iagnemma, K. and Dubowsky, S., Mobile robot rough-terrain control (RTC) for planetary exploration, Proceedings of the 26th ASME Biennial Mechanisms and Robotics Conference (2000).

飯塚浩二郎, 水上憲明, 大梘真嗣, 黒田洋司, 國井康晴, 久保田孝, 月面探査ロボット用車輪に搭載されているラグの 効果に関する考察, 第 25 回日本ロボット学会学術講演会 (2007).

Iizuka, K., Kunii, Y. and Kubota, T., Study on wheeled forms of lunar robots for traversing soft terrain, 2008 IEEE/RSJ International Conference on Intelligent Robots and Systems (2008), pp. 2010-2015.

Ishigami, G., Miwa, A., Nagatani, K. and Yoshida, K., Terramechanics-based model for steering maneuver of planetary exploration rovers on loose soil, The Journal of Field Robotics, Vol. 24, Issue 3 (2007), pp. 233-250.

石上玄也, 大槻真嗣, 久保田孝, テラメカニクスに基づいた弾性車輪および剛性車輪の力学モデルの提案, 第 12 回運 動と振動の制御シンポジウム (MOVIC2011) (2011), pp. 90-95.

Janosi, Z. and Hanamoto, B., The analytical determination of drawbar pull as a function of slip for tracked vehicles in deformable soils, Proceeding of the 1st International Conference for Terrain-Vehicle Systems (1961). 
水上憲明, 石上玄也, 國井康晴, 吉光徹雄, 久保田孝, 沈下過渡状態を考慮に入れたテラメカニクスに基づく車輪モデ ルの実験的検討, 第 34 回テラメカニックス研究会 (2013), pp. 7-12.

成田伸一郎, 大梘真嗣, 若林幸子, 西田信一郎, 軟弱地盤上における低圧車輪のけん引力評価, 第 12 回運動と振動の 制御シンポジウム (MOVIC2011) (2011), pp. 72-75.

大槻真嗣, 水上憲明, 若林幸子, 成田伸一郎, 西田信一郎, 惑星探査ローバの砂上走行効率化のための加減速方法の提 案, Dynamics and Design Conference 2010 (D\&D2010) (2010).

Reina, G., Ojeda, L., Milella, A. and Borenstein, J., Wheel slippage and sinkage detection for planetary rovers, IEEE/ASME Transactions on Mechatronics, Vol. 11, No. 2 (2006), pp. 185-195.

須藤真玩, 永谷圭司, 吉田和哉, 軟弱地盤における車輪型移動ロボットの走行性能に車輪表面形状が及ぼす影響の評 価, 第 12 回運動と振動の制御シンポジウム (MOVIC2011) (2011), pp. 106-111.

Wong, J. Y. and Reece, A. R., Prediction of rigid wheel performance based on the analysis of soil-wheel stresses part I. performance of driven rigid wheels, Journal of Terramechanics, Vol.4, Issue 1 (1967), pp. 81-98.

Wong, J. Y., Theory of ground vehicles (1978), John Wiley \& Sons, Inc.

Yoshida, K. and Hamano, H., Motion dynamics of a rover with slip-based traction model, Proceedings of the 2002 IEEE International Conference on Robotics and Automation(ICRA '02) (2002), pp. 3155-3160.

\section{References}

Bekker, M. G., Theory of land locomotion (1956), The University of Michigan Press.

Brooks, C., Iagnemma, K. and Dubowsky, S., Vibration-based terrain analysis for mobile robots, Proceeding of the 2005 IEEE International Conference on Robotics and Automation (2005), pp. 3415-3420.

Gu, K., Wei, Y. and Zhao, H. W. M., Dynamic modeling and sliding mode driving control for lunar rover slip, Proceedings of the 2007 IEEE International Conference on Integration Technology (2007), pp. 36-41.

Iagnemma, K. and Dubowsky, S., Mobile robot rough-terrain control (RTC) for planetary exploration, Proceedings of the 26th ASME Biennial Mechanisms and Robotics Conference (2000).

Iizuka, K., Mizukami, N., Otsuki, M., Kuroda, Y., Kunii, Y. and Kubota, T., Study on effect of lugs installed on wheels for lunar exploration robot, The 25th Annual Conference of the Robotics Society of Japan (2007) (in Japanese).

Iizuka, K., Kunii, Y. and Kubota, T., Study on wheeled forms of lunar robots for traversing soft terrain, 2008 IEEE/RSJ International Conference on Intelligent Robots and Systems (2008), pp. 2010-2015.

Ishigami, G., Miwa, A., Nagatani, K. and Yoshida, K., Terramechanics-based model for steering maneuver of planetary exploration rovers on loose soil, The Journal of Field Robotics, Vol. 24, Issue 3 (2007), pp. 233-250.

Ishigami, G., Otsuki, M. and Kubota, T., Terramechanics-based model for flexible/rigid wheels in rough terrain, The 12th Dynamics and Design Conference, Motion and vibration control(MOVIC2011) (2011), pp. $90-95$ (in Japanese).

Janosi, Z. and Hanamoto, B., The analytical determination of drawbar pull as a function of slip for tracked vehicles in deformable soils, Proceeding of the 1st International Conference for Terrain-Vehicle Systems (1961).

Mizukami, N., Ishigami, G., Kunii, Y., Yoshimitsu, T. and Kubota, T., Experimental study of wheel contact model in the process of wheel sinking, The 34th Annual Meeting of Japanese Society for Terramechanics, Vol.34 (2013), pp. 7-12 (in Japanese).

Narita, S., Otsuki, M., Wakabayashi, S. and Nishida, S., Drawbar pull evaluation of low-pressure wheel on deformable terrain, The 12th Dynamics and Design Conference, Motion and vibration control(MOVIC2011) (2011), pp. 72-75 (in Japanese).

Otsuki, M., Mizukami, N., Wakabayashi, S., Narita, S. and Nishida, S., Synthesis of acceleration profile to promote efficiency for traveling on sand by planetary rover, Dynamics and Design Conference 2010 (D\&D2010) (2010) (in Japanese).

Reina, G., Ojeda, L., Milella, A. and Borenstein, J., Wheel slippage and sinkage detection for planetary rovers, IEEE/ASME Transactions on Mechatronics, Vol. 11, No. 2 (2006), pp. 185-195.

Sutoh, M., Nagatani, K. and Yoshida, K., Evaluation of influence of surface shape of wheel on traversability of wheeled mobile robots on loose soil, The 12th Dynamics and Design Conference, Motion and vibration control(MOVIC2011) (2011), pp. 106-111 (in Japanese).

Wong, J. Y. and Reece, A. R., Prediction of rigid wheel performance based on the analysis of soil-wheel stresses part I. performance of driven rigid wheels, Journal of Terramechanics, Vol.4, Issue 1 (1967), pp. 81-98. 
Wong, J. Y., Theory of ground vehicles (1978), John Wiley \& Sons, Inc.

Yoshida, K. and Hamano, H., Motion dynamics of a rover with slip-based traction model, Proceedings of the 2002 IEEE International Conference on Robotics and Automation(ICRA ’02) (2002), pp. 3155-3160. 